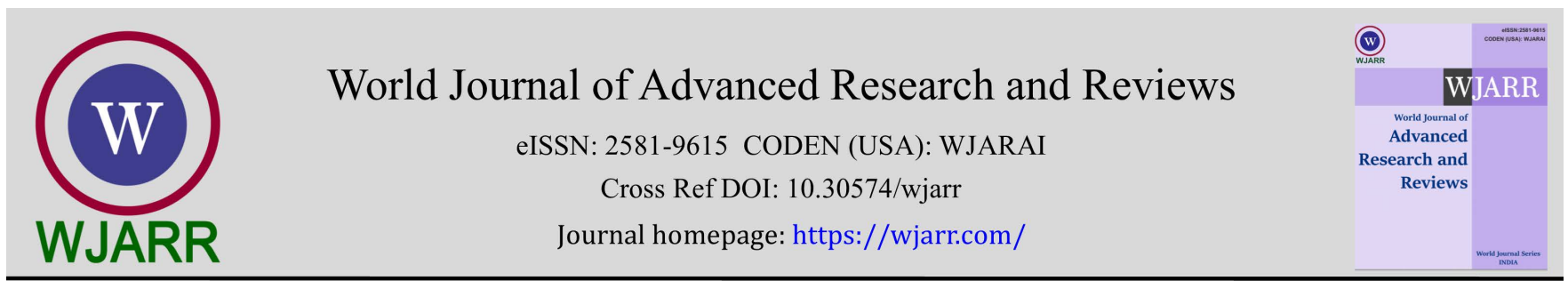

(RESEARCH ARTiClE)

\title{
Influence of coupled application of potassium and boron on growth and yield of late sown mungbean
}

\author{
Mohshina Mustare Liza 1, Alak Barman 2,*, Swarna Shome 1, Md. Eliyachur Rahman ${ }^{3}$ and Polly 4 \\ ${ }^{1}$ Department of Agronomy, Sher-e-Bangla Agricultural University, Dhaka, Bangladesh. \\ ${ }^{2}$ Soil Science Division, Bangladesh Agricultural Research Institute, Gazipur, Bangladesh. \\ ${ }^{3}$ Department of Agricultural Chemistry, Sher-e-Bangla Agricultural University, Dhaka, Bangladesh. \\ ${ }^{4}$ Department of Horticulture, First Capital University of Bangladesh, Chuadanga, Bangladesh.
}

World Journal of Advanced Research and Reviews, 2021, 11(01), 256-264

Publication history: Received on 18 June 2021; revised on 27 July 2021; accepted on 29 July 2021

Article DOI: https://doi.org/10.30574/wjarr.2021.11.1.0343

\begin{abstract}
To ensure both food and nutritional security of teeming millions of Bangladesh, cropping intensity must be increased along with nutritional food production. Mungbean, which is an important source of protein, can easily cope with the intensive cropping system due to short duration. But sometimes, to obtain maximum productivity per unit area in a calendar year, mungbean cannot be sown in optimum time. Considering this, a field study was carried out at Sher-eBangla Agricultural University to explore the effect of additional potassium and boron application to increase the yield of late sown mungbean which was sown on 25 October. The experiment was laid out in randomized complete block design with three replications and five treatments. Results revealed that additional potassium and boron along with recommended fertilizer dose had significant influence on growth, yield and yield contributing characters of late sown mungbean. The growth and yield of late sown mungbean is hampered due to temperature stress which cannot be overcome by recommended dose only but can be by addition of extra potassium and boron with recommended dose. The highest seed yield (1.12 $\mathrm{t} \mathrm{ha}^{-1}$ ) was obtained from recommended dose along with $10 \mathrm{Kg} \mathrm{K}$ and $2 \mathrm{Kg} \mathrm{B}^{-1}$ which was $40 \%$ higher than recommended dose only. Similar results were recorded for other parameters also. So, supplementation of recommended dose with $10 \mathrm{Kg} \mathrm{K}$ and $2 \mathrm{Kg} \mathrm{B}$ may be suggested to increase growth and yield of late sown mungbean.
\end{abstract}

Keywords: Biological yield; Fertilizer; Harvest index; Pulse crop; Sowing time

\section{Introduction}

Pulses are traditionally popular as poor man's meat in Bangladesh because of being the cheapest source of protein [1]. But as price hikes due to less production, now it has gone beyond the reach of poor people. In Bangladesh, per capita consumption of pulses is only $14.72 \mathrm{~g}$ [2] against the World Health Organization recommended requirement of $45.0 \mathrm{~g}$. So time demands to increase pulse production immediately to attain the daily intake requirement. Mungbean (Vigna radiata $L_{\text {. }}$ ), a leguminous crop is the third most important pulse crop in Bangladesh in both area and production [2]. It contains $51 \%$ carbohydrate, $26 \%$ protein, $4 \%$ minerals and 3\% vitamins [3]. Due to its short duration and year-round cultivation, mungbean can well fit in cropping system while improve the physical, chemical and biological properties and overall soil fertility status due to its nitrogen fixing ability [4]. But to fit in the intensive cropping system for ensuring food security, sometimes mungbean has to be sown in October instead of September which causes the yield reduction due to temperature stress. But the yield loss can be overcome by supplementation with potassium and boron fertilizer. K fertilizer enhances sugar metabolism, increases osmotic cell concentration, regulates stomatal guard cell turgor, helps in stomatal opening and photosynthesis, improves drought resistance, and increases yield [5]. On the other hand, boron

${ }^{*}$ Corresponding author: Alak Barman

Soil Science Division, Bangladesh Agricultural Research Institute, Gazipur, Bangladesh.

Copyright (C) 2021 Author(s) retain the copyright of this article. This article is published under the terms of the Creative Commons Attribution Liscense 4.0. 
has profound impact on plant nutrition and recognized as major yield limiting factor in pulses [6]. It plays a vital role in chlorophyll synthesis as well as carbohydrates metabolism. The most crucial role of boron is in activating the germination of pollen, accelerating the growth of pollen tube and increasing the number of flowers and fruits formation [7]. In Bangladesh, many studies have been conducted on nutrient requirements of mungbean, but reports are very few on the combined supplementation of potassium and boron fertilizer to improve the yield of late sown mungbean. Therefore, the experiment was conducted to explore the optimum doses of potassium and boron supplement to ameliorate the growth and yield of late sown mungbean.

\section{Material and methods}

\subsection{Experimental site}

The field experiment was laid out at Sher-e-Bangla Agricultural University Farm, Bangladesh during the period during Rabi season. The experimental area was situated between 23074/ latitude and 95035/ longitude. It belongs to subtropical climate. The land of the selected experimental plot is under Madhupur Tract with shallow red brown terrace soil [8].

\subsection{Experimental design and treatments}

BARI Mung-6, a photo insensitive, high yield variety, developed by Bangladesh Agricultural Research institute, was used as a test crop. The experiment was conducted following Randomized Complete Block Design (RCBD) with three replications. The experiment consisted of five treatments viz. $\mathrm{F}_{0}=$ Recommended dose ( $\mathrm{R}$ ) [9], $\mathrm{F}_{1}=\mathrm{R}+\mathrm{Additional} 10 \mathrm{~kg}$ $\mathrm{K} \mathrm{ha}^{-1}+1 \mathrm{~kg} \mathrm{~B} \mathrm{ha}^{-1}, \mathrm{~F}_{2}=\mathrm{R}+$ Additional $20 \mathrm{~kg} \mathrm{~K} \mathrm{ha}^{-1}+1 \mathrm{~kg} \mathrm{~B} \mathrm{ha}^{-1}, \mathrm{~F}_{3}=\mathrm{R}+$ Additional $10 \mathrm{~kg} \mathrm{~K} \mathrm{ha}^{-1}+2 \mathrm{~kg} \mathrm{~B} \mathrm{ha}^{-1}$ and F $\mathrm{F}_{4}=\mathrm{R}+$ Additional $20 \mathrm{~kg} \mathrm{~K} \mathrm{ha}^{-1}+2 \mathrm{~kg} \mathrm{~B} \mathrm{ha}^{-1}$. The unit plot size was $3 \mathrm{~m}^{2}(2 \mathrm{~m} \times 1.5 \mathrm{~m})$.

\subsection{Sowing and management of crop}

The land of the experimental plot was prepared with a power tiller on 23 October, 2013. The full amount of N, P, K and $\mathrm{B}$ was applied at the time of final land preparation in the forms of urea, triple super phosphate, muriate of Potash and boric acid, respectively. The experimental plots were fertilized according to treatments. Mungbean (var. BARI Mung-6) seed was sown on 25 October in rows maintaining row to row distance $30 \mathrm{~cm}$ and seed to seed distance $10 \mathrm{~cm}$. Crop management activities were done when needed. Thinning was done at 7 days after emergence of seed for every sowing time. Weeding was done at 20-25 days after emergence of seed. Mulching was done at 30-35 days after emergence of seedlings. Irrigation and pesticide were given as per necessity.

\subsection{Harvesting and Data collection}

Data on plant height, dry matter of leaves and stem was measured from 20 to 60 DAS with 10 days interval. Dry matter was determined by uprooting three plants from each plot and drying them in oven. Days to flowering, pod length (cm), no. of pods plant ${ }^{-1}$, and no. of seeds pod ${ }^{-1}$ were recorded from ten pre-selected plant. Thousands seed weight, seed yield, stover yield, biological yield and harvest index were recorded after harvesting, threshing and drying. Harvesting was done when $90 \%$ of the pod became blackish in color. Before harvesting 3 sampling plants from each plot was selected randomly and harvested for recording the data on different yield contributing characters. The crop was harvested from central $1.0 \mathrm{~m}^{2}$ area excluding border area. The pods from were collected at each harvest time plot wise and were bagged separately, tagged and brought to the threshing floor for yield data. Seed yield was determined at $12 \%$ moisture content. The stover yield was taken from the plants of the same area by sun-drying. Harvest index is the ratio of economic yield to biological yield and was calculated with the following formula:

$$
\text { Harvest index }(\%)=\frac{\text { Grain yield }}{\text { Biological yield }} \times 100
$$

\subsection{Data analysis}

The collected data was compiled and analyzed statistically using the analysis of variance (ANOVA) technique with the help MSTAT-C software and the mean differences were adjusted by Least Significance Difference (LSD) test at 5\% probability level [10]. 


\section{Results and discussion}

\subsection{Plant height}

Plant height varied significantly by different levels of potassium and boron fertilizer doses (Figure 1) throughout the growing period except 20, 40 and 50 DAS. At 30 DAS, $\mathrm{F}_{4}\left(\mathrm{R}+\right.$ Additional $\left.20 \mathrm{~kg} \mathrm{~K} \mathrm{ha}^{-1}+2 \mathrm{~kg} \mathrm{~B} \mathrm{ha}^{-1}\right)$ gave the tallest plant $(30.96 \mathrm{~cm})$ which was statistically similar with $\mathrm{F}_{3}(28.1 \mathrm{~cm})$ and at $60 \mathrm{DAS} \mathrm{F}_{3}\left(\mathrm{R}+\right.$ Additional $\left.10 \mathrm{~kg} \mathrm{~K} \mathrm{ha}^{-1}+2 \mathrm{~kg} \mathrm{~B} \mathrm{ha}^{-1}\right)$ gave the tallest plant $(40.03 \mathrm{~cm})$. At $30 \mathrm{DAS} \mathrm{F}_{0}$ (Recommended dose) gave the shortest plant $(27.96 \mathrm{~cm})$. At $60 \mathrm{DAS}, \mathrm{F}_{2}$ gave the shortest $(35.23 \mathrm{~cm})$ plant which was statistically similar with $\mathrm{F}_{0}$.

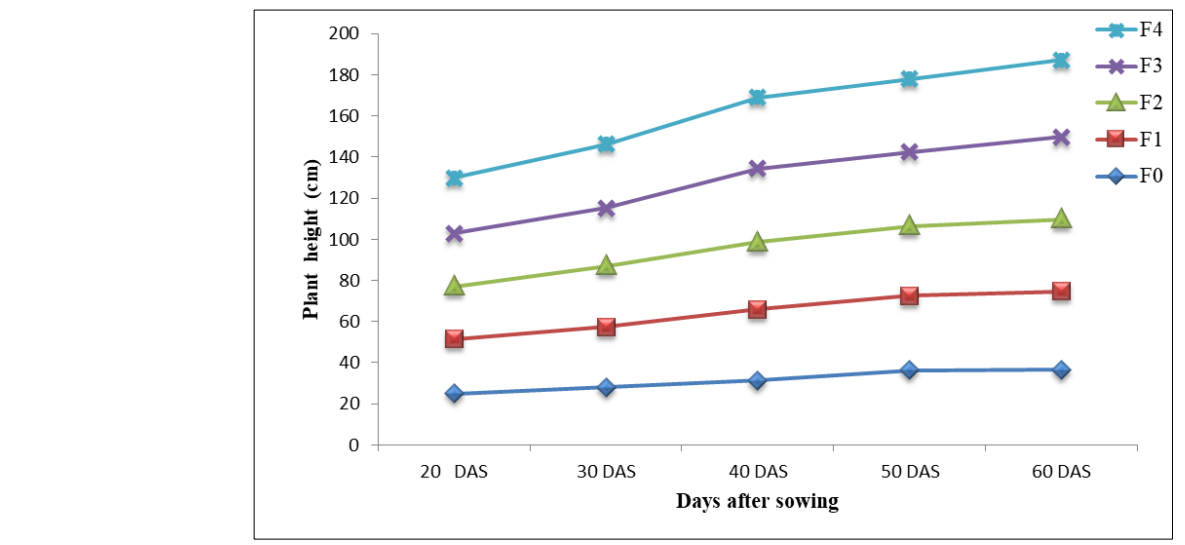

$\mathrm{F}_{0}=$ Recommended dose (R), $\mathrm{F}_{1}=\mathrm{R}+$ Additional $10 \mathrm{~kg} \mathrm{~K} \mathrm{ha}^{-1}+1 \mathrm{~kg} \mathrm{~B} \mathrm{ha}^{-1}, \mathrm{~F}_{2}=\mathrm{R}+$ Additional $20 \mathrm{~kg} \mathrm{~K} \mathrm{ha}^{-1}+1 \mathrm{~kg} \mathrm{~B} \mathrm{ha}^{-1}$, $\mathrm{F} 3=\mathrm{R}+$ Additional $10 \mathrm{~kg} \mathrm{~K} \mathrm{ha}^{-1}+2 \mathrm{~kg} \mathrm{~B} \mathrm{ha}^{-1}, \mathrm{~F}_{4}=\mathrm{R}+$ Additional $20 \mathrm{~kg} \mathrm{~K} \mathrm{ha}^{-1}+2 \mathrm{~kg} \mathrm{~B} \mathrm{ha}^{-1}$

Figure 1 Plant height of mungbean at different DAS as influenced by different level of potassium and boron fertilizer dose (LSD value $=3.90,2.88,5.78,3.25$ and 1.75 at 20, 30, 40, 50 and 60 DAS, respectively)

Gowthmi and Rama [11] stated that application of potassium nitrate and boric acid increased the plant height. Hussain et al. [12] stated that increased amount of potassium levels significantly affected the plant height. Significant increase in plant height induced by different doses of B was observed in mungbean [13]. The increase in plant height by K might be due to enhanced photosynthetic rate thereby encouraging the vegetative growth [14]. Furthermore, B is essential for cell division and cell elongation resulting in enhanced plant growth and plant height [15].

\subsection{Dry matter of leaf}

Figure 2 depicted dry matter of leaf influenced by additional application of potassium and boron throughout the growing period. Maximum dry matter was obtained at 40 DAS among all the sampling dates. At 30, 40, 50 DAS, highest dry matter of leaf $\left(0.48,1.42,0.89 \mathrm{~g}\right.$, respectively) was found from $\mathrm{F}_{3}\left(\mathrm{R}+\right.$ Additional $\left.10 \mathrm{~kg} \mathrm{~K} \mathrm{ha}^{-1}+2 \mathrm{~kg} \mathrm{~B} \mathrm{ha}^{-1}\right)$ fertilizer dose. At 30 DAS lowest dry matter of leaf $(0.26 \mathrm{~g})$ was recorded from $\mathrm{F}_{1}$ which is statistically similar with $\mathrm{F}_{0}$

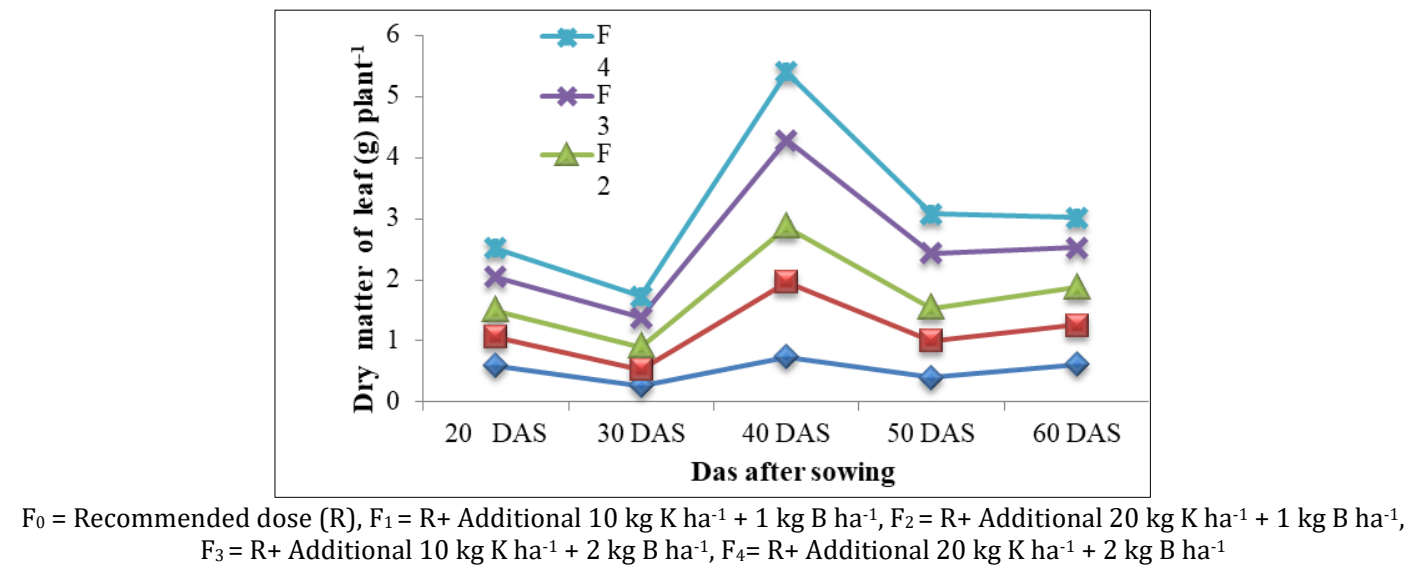

Figure 2 Effect of different levels potassium and boron fertilizer dose on dry matter of leaf of mungbean plant at different DAS (LSD = 0.19, 0.05, 0.16, 0.17, 0.18 at 20, 30, 40, 50 and 60 DAS, respectively) 
The lowest dry matter of leaf $(0.74,0.40 \mathrm{~g})$ was obtained from $\mathrm{F}_{0}$ (Recommended dose) at 40, 50 DAS, respectively. Gowthmi and Rama [11] stated that application of potassium nitrate and boric acid increased the total dry matter of plant. This result is in agreement with [16] who reported that B showed greater performance to leaf-stem, total dry matter weight of plant. Muhlbachova et al. [17] have found positive correlation between dry matter yield and B contents in Barley. According to Han et al. [18], B deficiency influence plant growth by reducing enzymatic activities and lowering stomatal conductance and $\mathrm{CO}_{2}$ assimilation in plant leaves.

\subsection{Dry matter of stem}

Figure 3 illustrated dry matter of stem of mungbean at 20, 30, 40, 50 and 60 DAS. Significant variation was observed by different levels of potassium and boron fertilizer doses for dry matter production of stem throughout the growing period except 20, 30, 60 DAS. At 40 DAS the highest dry matter of stem $(0.97 \mathrm{~g})$ was recorded from $F_{1}(\mathrm{R}+$ Additional $\left.10 \mathrm{~kg} \mathrm{~K} \mathrm{ha}^{-1}+1 \mathrm{~kg} \mathrm{~B} \mathrm{ha}^{-1}\right)$. At 50 DAS the highest dry matter of stem $(0.68 \mathrm{~g})$ was recorded from $\mathrm{F}_{0}$ which was statistically similar with $F_{1}$ and $F_{3}$. At 40 and 50 DAS the lowest $\left(0.23\right.$ and $0.37 \mathrm{~g}$ ) was found from $F_{2}$. The ability of potassium to improve dry matter was reported by [19]. The positive effect of potassium sources and boron combination treatment on starch could be interpreted by multiple physiological functions of both elements. Potassium plays an important role in promoting photosynthesis and increasing transport its products to sink [20] while boron increases the rate of photosynthesis by affecting photophosphorylation process inside chloroplasts and shifts the hormonal balance in leaves and stem especially IAA which is important for growth [21]. Boron has positive role in transporting carbohydrates from source to sink while its deficiency retards the synthesis of nucleic acids, carbohydrates metabolism and ultimately reduce biomass [22].

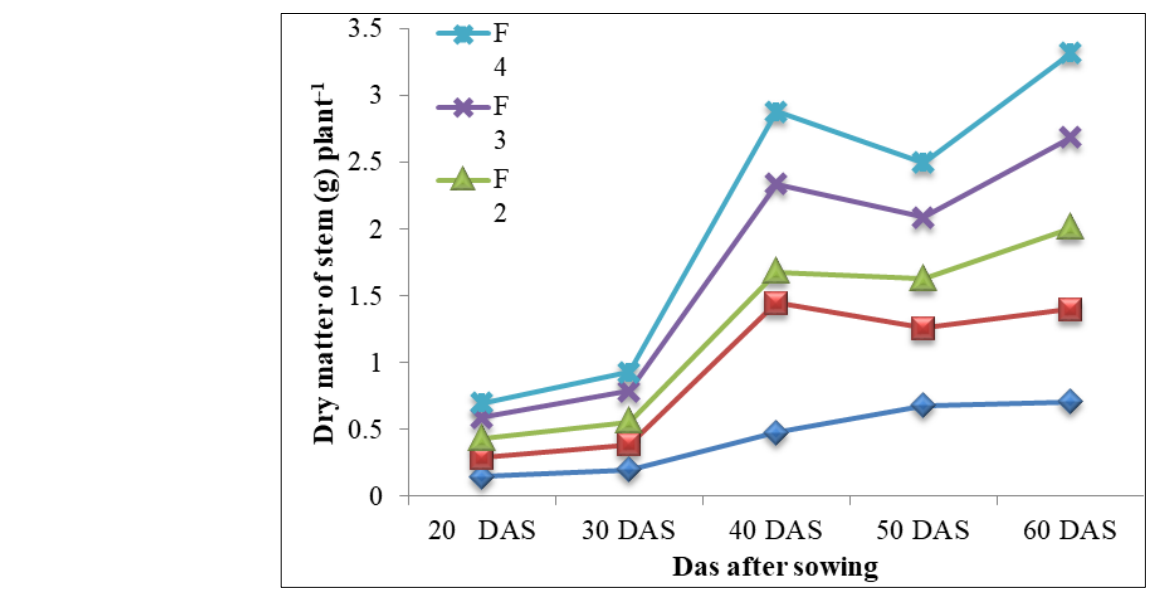

$\mathrm{F}_{0}=$ Recommended dose (R), $\mathrm{F}_{1}=\mathrm{R}+$ Additional $10 \mathrm{~kg} \mathrm{~K} \mathrm{ha}^{-1}+1 \mathrm{~kg} \mathrm{~B} \mathrm{ha}^{-1}, \mathrm{~F}_{2}=\mathrm{R}+$ Additional $20 \mathrm{~kg} \mathrm{~K} \mathrm{ha}^{-1}+1 \mathrm{~kg} \mathrm{~B} \mathrm{ha}^{-1}$, $\mathrm{F}_{3}=\mathrm{R}+$ Additional $10 \mathrm{~kg} \mathrm{~K} \mathrm{ha}^{-1}+2 \mathrm{~kg} \mathrm{~B} \mathrm{ha}^{-1}, \mathrm{~F}_{4}=\mathrm{R}+$ Additional $20 \mathrm{~kg} \mathrm{~K} \mathrm{ha}^{-1}+2 \mathrm{~kg} \mathrm{~B} \mathrm{ha}^{-1}$

Figure 3Effect of different levels potassium and boron fertilizer dose on dry matter of stem mungbean plant at different DAS (LSD = 0.05, 0.11, 0.13, 0.23 and 0.33 at 20, 30, 40, 50 and 60 DAS, respectively)

\subsection{Pod length}

Due to different levels of potassium and boron fertilizer doses, pod length of mungbean did not vary significantly (Table 1). But numerically, the longest pod $(5.76 \mathrm{~cm})$ was obtained from $\mathrm{F}_{1}\left(\mathrm{R}+\right.$ Additional $\left.10 \mathrm{~kg} \mathrm{~K} \mathrm{ha}-1+1 \mathrm{~kg} \mathrm{~B} \mathrm{ha}^{-1}\right)$ and shortest $(5.35 \mathrm{~cm})$ was found in $\mathrm{F}_{3}\left(\mathrm{R}+\right.$ Additional $\left.10 \mathrm{~kg} \mathrm{~K} \mathrm{ha}^{-1}+2 \mathrm{~kg} \mathrm{~B} \mathrm{ha}^{-1}\right)$. These findings were similar with Jahan et al. [23].

\subsection{No. of pods plant ${ }^{-1}$}

Statistically non-significant variations in no. of pods plant ${ }^{-1}$ was observed at different levels of potassium and boron fertilizer dose (Table 1). But numerically, the treatment $\mathrm{F}_{1}\left(\mathrm{R}+\right.$ Additional $10 \mathrm{~kg} \mathrm{~K} \mathrm{ha}^{-1}+1 \mathrm{~kg} \mathrm{~B}^{-1}$ ) gave the highest no. of pods plant ${ }^{-1}(11.53)$ and the treatment $\mathrm{F}_{4}\left(\mathrm{R}+\right.$ Additional $\left.20 \mathrm{~kg} \mathrm{~K} \mathrm{ha}^{-1}+2 \mathrm{~kg} \mathrm{~B} \mathrm{ha}^{-1}\right)$ gave the lowest no. of pods plant -1 (9.72). The results are almost same as reported by Samiullah and Khan [24]. 
Table 1 Yield contributing character of mungbean influenced by different levels of potassium and boron fertilizer dose

\begin{tabular}{llllll}
\hline Treatment & Pod length (cm) & $\begin{array}{l}\text { No. of pods } \\
\text { plant }^{-1}\end{array}$ & $\begin{array}{l}\text { No. of seeds } \\
\text { pod }^{-1}\end{array}$ & 1000-seed weight (g) & Days to flower
\end{tabular}

\begin{tabular}{|c|c|c|c|c|c|}
\hline $\mathbf{F}_{\mathbf{0}}$ & 5.61 & 10.05 & $6.14 \mathrm{ab}$ & $30.38 c$ & $37.17 \mathrm{a}$ \\
\hline $\mathbf{F}_{1}$ & 5.76 & 11.53 & $7.10 \mathrm{a}$ & $36.90 \mathrm{ab}$ & $34.67 \mathrm{ab}$ \\
\hline $\mathbf{F}_{2}$ & 5.52 & 10.05 & $5.22 \mathrm{~b}$ & $34.98 \mathrm{~b}$ & $32.00 \mathrm{~cd}$ \\
\hline $\mathbf{F}_{3}$ & 5.34 & 11.44 & $6.84 \mathrm{ab}$ & $37.53 \mathrm{a}$ & $29.83 \mathrm{~d}$ \\
\hline $\mathbf{F}_{4}$ & 5.63 & 9.72 & $7.16 \mathrm{a}$ & $32.43 \mathrm{c}$ & $34.00 \mathrm{bc}$ \\
\hline $\operatorname{LSD}_{(0.05)}$ & NS & NS & 1.85 & 2.15 & 2.62 \\
\hline CV (\%) & 12.64 & 22.74 & 15.19 & 3.32 & 4.16 \\
\hline
\end{tabular}

\subsection{No. of seeds pod-1}

No. of seeds pod ${ }^{-1}$ was significantly influenced by different levels of potassium and boron fertilizer dose (Table 1). Results showed that the maximum no. of seeds pod ${ }^{-1}$ (7.16) was recorded from $\mathrm{F}_{4}\left(\mathrm{R}+\right.$ Additional $10 \mathrm{~kg} \mathrm{~K} \mathrm{ha-1}+2 \mathrm{~kg} \mathrm{~B}^{-1}$ ha $^{-1}$ ) fertilizer dose which was statistically similar with $F_{3}$ and $F_{1}$. The minimum no. of seeds pod ${ }^{-1}(5.22)$ was obtained with $\mathrm{F}_{2}$ which was statistically at par with $\mathrm{F}_{0}$ (Recommended dose). This result was supported by Valenciano et al. [16] who reported boron increased the no. of Seeds pod-1. Haque [25] reported that number of seeds pod-1 increased with increasing levels of K. On the other hand, improved B nutrition lowers the sterility in bread wheat from $42.6-45 \%$ thereby increases grain yield [26].

\subsection{0-seed weight}

Weight of 1000-seed was significantly influenced by different levels of potassium and boron fertilizer dose (Table 1). Result showed that the highest 1000 -seed weight (37.53 g)was observed from $\mathrm{F}_{3}$ (R+Additional $10 \mathrm{~kg} \mathrm{~K} \mathrm{ha-1}+2 \mathrm{~kg} \mathrm{~B}$ $\mathrm{ha}^{-1}$ ) fertilizer dose and the lowest (30.38 g) from $\mathrm{F}_{0}$ (Recommended dose). Kaisher et al. [27] documented higher 1000 seed weight due to boron application. Haque [25]stated thatweight of 1000 seeds increased with increasing levels of K. Alam et al. [28] have observed the increase in 1000-seed weight of summer mungbean under the combined fertilization of $\mathrm{K}$ and $\mathrm{B}$.

\subsection{Days to flower}

Significant variation was observed in days to flower due to different levels of potassium and boron fertilizer dose (Table 1). Results showed that the highest days to flower (37.17 days) was recorded with $F_{0}$ (Recommended dose) fertilizer dose which was statistically at par with $\mathrm{F}_{1}\left(\mathrm{R}+\right.$ Additional $\left.10 \mathrm{~kg} \mathrm{~K} \mathrm{ha}^{-1}+1 \mathrm{~kg} \mathrm{~B} \mathrm{ha}^{-1}\right)$ and the lowest days to flower (29.83 days) with $\mathrm{F}_{3}\left(\mathrm{R}+\right.$ Additional $10 \mathrm{~kg} \mathrm{~K} \mathrm{ha}^{-1}+2 \mathrm{~kg} \mathrm{~B} \mathrm{ha}^{-1}$ ) which was statistically similar with $\mathrm{F}_{2}$ ( $\mathrm{R}+\mathrm{Additional} 20 \mathrm{~kg} \mathrm{~K}$ $\mathrm{ha}^{-1}+1 \mathrm{~kg} \mathrm{~B} \mathrm{ha}^{-1}$ ) fertilizer dose. Maqbool et al. [29] also found that B had significant influence on flowering habit of mungbean.

\subsection{Seed yield}

Seed yield showed significant difference due to application of different levels of potassium and boron fertilizer dose on mungbean (Figure 4). All other doses showed highest seed yield than recommended doses. The highest seed yield (1.12 $\left.\mathrm{t} \mathrm{ha}^{-1}\right)$ was recorded with $\mathrm{F}_{3}\left(\mathrm{R}+\right.$ Additional $\left.10 \mathrm{~kg} \mathrm{~K} \mathrm{ha}^{-1}+2 \mathrm{~kg} \mathrm{~B} \mathrm{ha}^{-1}\right)$ fertilizer dose which was statistically similar with $\mathrm{F}_{1}, \mathrm{~F}_{2}$ and the lowest seed yield $\left(0.80 \mathrm{t} \mathrm{ha}^{-1}\right)$ was with $\mathrm{F}_{0}$ (Recommended dose). Addition of kg $10 \mathrm{~K} \mathrm{ha}^{-1}+2 \mathrm{~kg} \mathrm{~B} \mathrm{ha}^{-1}$ with recommended dose provided 40\% higher yield than recommended dose only. Kaisher et al. [27] and Quddus et al. [13] found that B significantly increased the yield of mungbean. Gowthmi and Rama [11] stated that application of potassium nitrate and boric acid increase the seed yield. The role of foliar application of different sources of potassium in increasing the yield and its components might be attributed to its function in plants which includes energy metabolism and enzyme activation that increase exchange rate and nitrogen activity as well as enhance carbohydrates movement from shoots to storage organs. This may be due to increase in the amount of chlorophyll in leaves and photosynthetic area which in turn leads to enhanced photosynthetic rate and ultimately accumulation of nutrients in seeds which improves yield. On 
the contrary, boron improves photosynthetic activity, enhances activity of enzymes and plays significant role in protein and nucleic acid metabolism [30]. In addition, the effect of B application on increased $\mathrm{K}$ uptake may be related to synergistic relationship between $\mathrm{K}$ and $\mathrm{B}$ at sugar and carbohydrate transport [31].

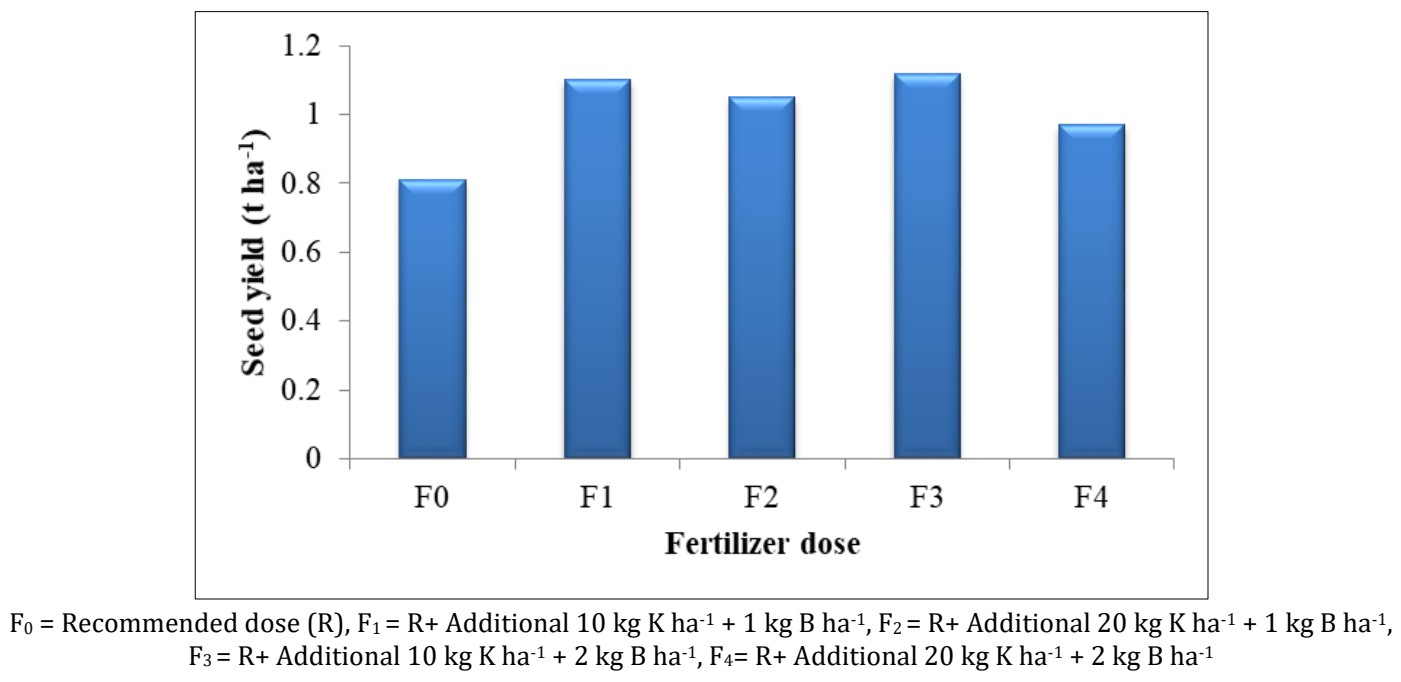

Figure 4 Seed yield of mungbean plant influenced by different levels of potassium and boron fertilizer doses $(\mathrm{LSD}=0.08)$

\subsection{Stover yield}

Application of different levels of potassium and boron fertilizer showed significant variation in term of stover yield (Figure 5). Results showed that the highest stover yield (1.81 t ha-1) was recorded from $\mathrm{F}_{1}\left(\mathrm{R}+\mathrm{Additional}^{-10} \mathrm{~kg} \mathrm{~K} \mathrm{ha-1}+\right.$ $\left.1 \mathrm{~kg} \mathrm{~B} \mathrm{ha}^{-1}\right)$ and the lowest $\left(0.71 \mathrm{t} \mathrm{ha}^{-1}\right)$ was observed from $\mathrm{F}_{2}\left(\mathrm{R}+\right.$ Additional $\left.20 \mathrm{~kg} \mathrm{~K} \mathrm{ha}^{-1}+1 \mathrm{~kg} \mathrm{~B} \mathrm{ha}^{-1}\right)$ which was statistically at par with $\mathrm{F}_{0}$ (Recommended dose). Similarly, this result was in line with Quddus et al. [13] and Haque [25].

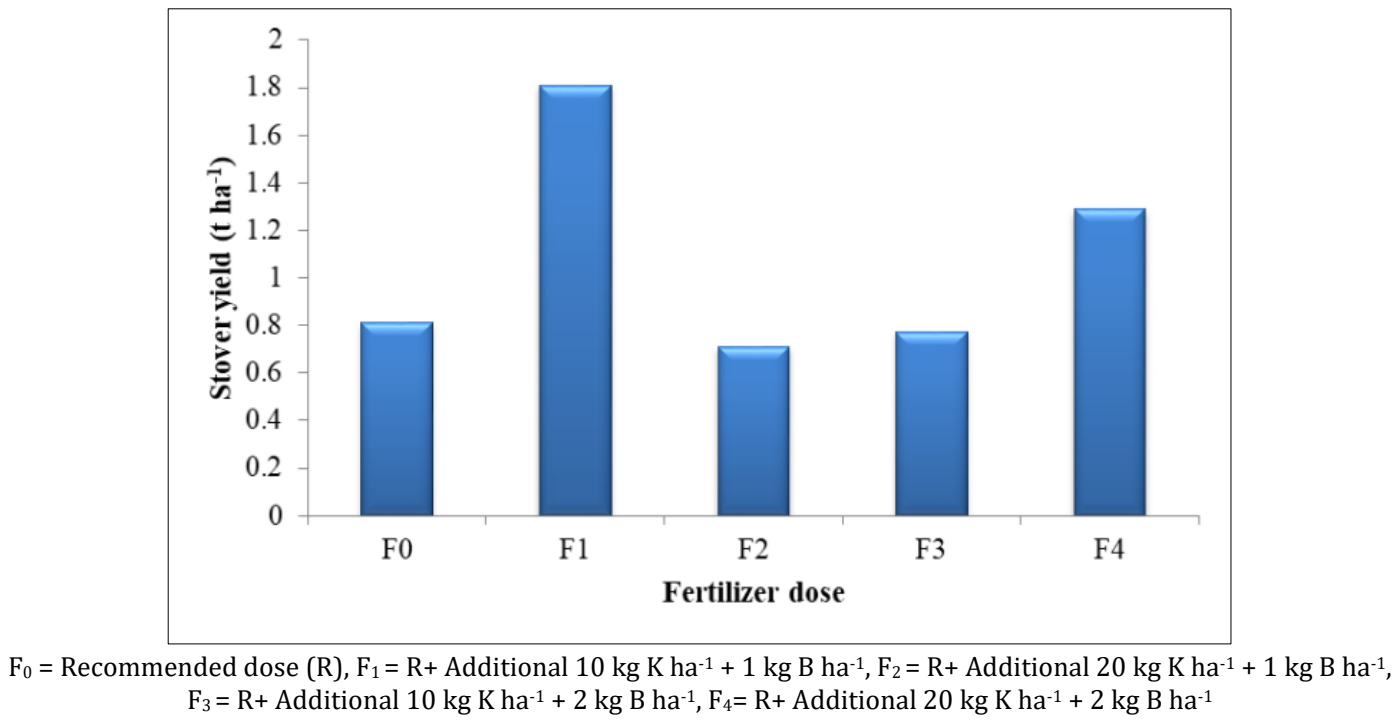

Figure 5 Stover yield of mungbean plant influenced by different levels of potassium and boron fertilizer doses $(\mathrm{LSD}=0.18)$

\subsection{Biological yield}

Different levels of potassium and boron fertilizer application significantly influenced the biological yield of mungbean in the present study (Figure 6). Application of $\mathrm{F}_{1}\left(\mathrm{R}+\right.$ Additional $10 \mathrm{~kg} \mathrm{~K} \mathrm{ha}^{-1}+1 \mathrm{~kg} \mathrm{~B} \mathrm{ha}^{-1}$ ) fertilizer dose showed the highest biological yield due to higher grain and stover yield and $\mathrm{F}_{0}$ (Recommended dose) showed the lowest biological yield due to poorer grain and stover yield. The present result is agreement with findings of Jahan et al. [23]. 


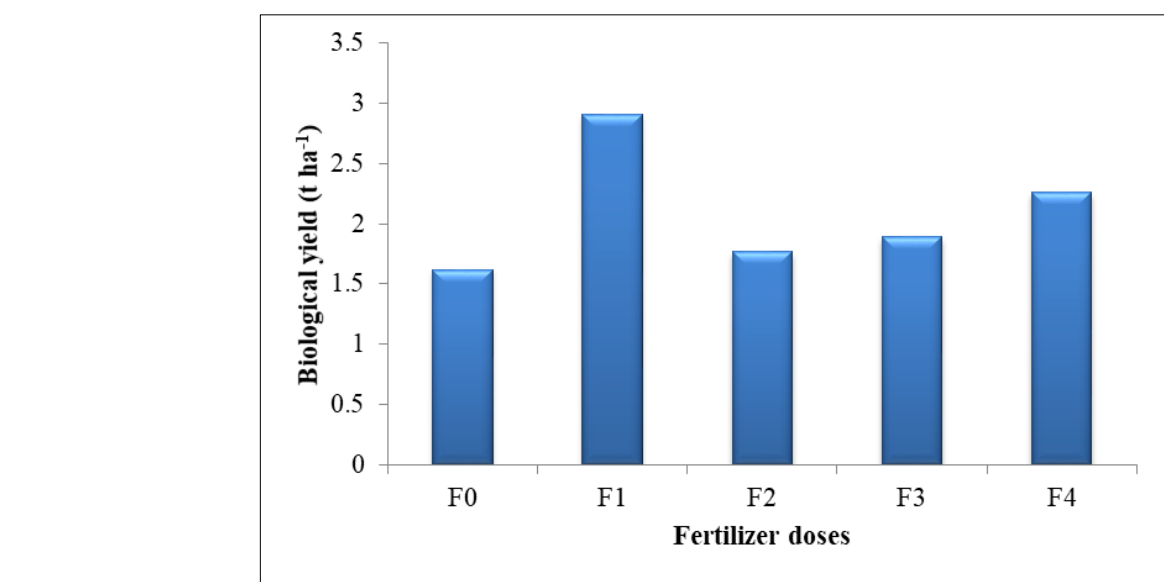

$\mathrm{F}_{0}=$ Recommended dose (R), $\mathrm{F}_{1}=\mathrm{R}+$ Additional $10 \mathrm{~kg} \mathrm{Kha}^{-1}+1 \mathrm{~kg} \mathrm{~B} \mathrm{ha}^{-1}, \mathrm{~F}_{2}=\mathrm{R}+$ Additional $20 \mathrm{~kg} \mathrm{~K} \mathrm{ha}^{-1}+1 \mathrm{~kg} \mathrm{~B} \mathrm{ha}^{-1}$, $\mathrm{F}_{3}=\mathrm{R}+$ Additional $10 \mathrm{~kg} \mathrm{~K} \mathrm{ha}^{-1}+2 \mathrm{~kg} \mathrm{~B} \mathrm{ha}^{-1}, \mathrm{~F}_{4}=\mathrm{R}+$ Additional $20 \mathrm{~kg} \mathrm{Kha}^{-1}+2 \mathrm{~kg} \mathrm{~B} \mathrm{ha}^{-1}$

Figure 6 Effect of different levels potassium and boron fertilizer doses on biological yield of mungbean (LSD value= $0.1)$

\subsection{Harvest index}

Harvest index was significantly varied by different levels of potassium and boron fertilizer (Figure 7). The Highest harvest index (60.2\%) was recorded from $\mathrm{F}_{2}\left(\mathrm{R}+\right.$ Additional $\left.20 \mathrm{~kg} \mathrm{~K} \mathrm{ha}^{-1}+1 \mathrm{~kg} \mathrm{~B} \mathrm{ha}^{-1}\right)$ which was statistically similar with $\mathrm{F}_{3}\left(\mathrm{R}+\right.$ Additional $\left.10 \mathrm{~kg} \mathrm{~K} \mathrm{ha}^{-1}+2 \mathrm{~kg} \mathrm{~B} \mathrm{ha}^{-1}\right)$ due to higher grain yield and poorer stover yield. The lowest (37.73 $\%)$ was found from $F_{1}\left(R+\right.$ Additional $\left.10 \mathrm{~kg} \mathrm{~K} \mathrm{ha}^{-1}+1 \mathrm{~kg} \mathrm{~B} \mathrm{ha}^{-1}\right)$ due to poorer grain yield and higher stover yield. Hamza et al. [4] also found similar results with the present study.

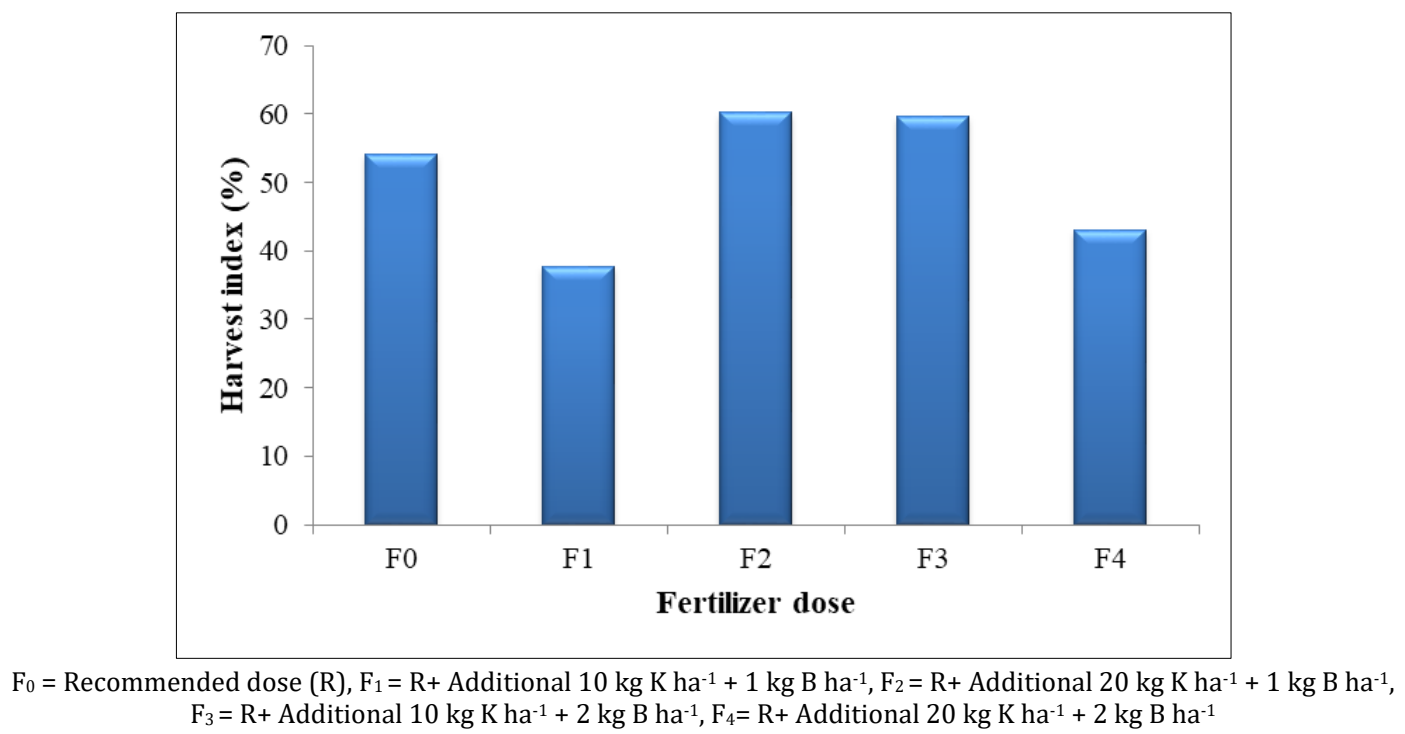

Figure 7 Effect of different levels potassium and boron fertilizer doses on harvest index (LSD value $=4.53$ )

\section{Conclusion}

Considering the above results, it may be concluded that, $10 \mathrm{~kg} \mathrm{~K}$ and $2 \mathrm{~kg} \mathrm{~B}$ with recommended dose might be helpful to overcome the yield loss and improve the growth and yield of late sown mungbean which is sown on 25 October. Further study will be required to find out suitable amount of potassium and boron supplementation for improving yield of mungbean sowing on different times of the year. 


\section{Compliance with ethical standards}

\section{Acknowledgments}

Authors would like to express their sincere gratitude to Head of the department of Agronomy and other concerned personnel of the department for valuable guide and support. The authors also like to thank the officials of Farm Division, Sher-e-Bangla Agricultural University, Dhaka, Bangladesh for their support to conduct the research.

\section{Disclosure of conflict of interest}

All the authors declare that there is no conflict of interest.

\section{References}

[1] Miah MAM, Akter MS, Bakr MA. Status of pulses varieties adoption in Bangladesh: A farm level study. Bangladesh Journal of Agricultural Economics. 2004; 27(2): 107-122.

[2] BBS (Bangladesh Bureau of Statistics). Statistical Year Book of Bangladesh. Bur. Stat. Div. Min Plan., Govt. People's Repub., Bangladesh, Dhaka. 2012; 47-133.

[3] Kaul AK. Pulses in Bangladesh. BRAC, Farm Gate, Dhaka. 1982; 27.

[4] Hamza BA, Chowdhury MAK, Rob MM, Miah I, Habiba U, Rahman MZ .Growth and yield response of mungbean as influenced by phosphorus and boron application. American Journal of Experimental Agriculture. 2016; 11(3): 17.

[5] Liang J, Yin ZC, Wang YJ, Xiao HY, Zhang WQ, Yin FX. Effects of different density and fertilizer application methods on the yield of mungbean. Journal of Horticulture and Seed. 2011; 6: 81-83.

[6] Ali M, Singh KK, Soad AA. Balance fertilization for nutritional quality in pulses. Fertilizer News. 2004; 49(4): 47 56.

[7] Laxmi S, Patel R, Singh S, Choudhary B, Gadhwal R, Meena R, Singh YV. International Journal of Current Microbiology and Applied Science. 2020; 9(3): 2788-2794.

[8] UNDP. Land Resources Appraisal of Bangladesh for Agricultural Development Report 2: Agro-ecological Regions of Bangladesh, FAO, Rome. 1988; 212-577.

[9] FRG (Fertilizer Recommendation Guide). Bangladesh Agricultural Research Council (BARC), Farmgate, Dhaka, Bangladesh. 2012; 102.

[10] Gomez KA, Gomez AA. Statistical Procedures for Agricultural Research. $2^{\text {nd }}$ Edn. John Willey and Sons, New York. 1984; 97-411.

[11] Gowthami P, Rama RG. Influence of foliar application of Potassium, Boron and Zinc on growth and yield of bean. Journal of Agricultural Legumes. 2013; 4(3): 81-86.

[12] Hussain F, Malik AU, Malghani AL. Growth and yield responses of two cultivars of mungbean (Vigna radiata L.) to different potassium level. Journal of Animal and Plant. Science. 2011; 21(3): 622-625.

[13] Quddus MA, Rashid MH, Hossain MA, Naser HM. Effect of zinc and boron on yield and yield contributing characters of Mungbean in low ganges river floodplain soil at Madaripur, Bangladesh. Bangladesh Journal of Agricultural Research. 2011; 36(1): 75-85.

[14] El-Habbasha SF, Hozayn M, Khalafallah A. Integration effect between phosphorus levels and biofertilizers on quality and quantity yield of faba bean (Vicia faba L.) in newly cultivated sandy soils. Research Journal of Agriculture and Biological Sciences. 2007; 3: 966-971.

[15] Juan J, Camacho C, Esperanza M, Martin-Rejano, M. Begona Herrera-Rodriguez M, Navarro-Gochicoa T, Rexach J, Gonzalez-Fontes A. Boron deficiency inhibits root cell elongation via an ethylene/auxin/ROS-dependent pathway in Arabidopsis seedlings. Journal of Experimental Botany. 2015; 66(13): 3831-3840.

[16] Valenciano JB, Boto JA, Marcelo V. Response of chickpea (Cicer arietinum) yield to zinc, boron and molybdenum application under pot conditions. Spanish Journal of Agricultural Research. 2010; 8(3): 797-807. 
[17] Muhlbachova G, Cermak P, Vavera R, Kas M, Pechova M, Markova K, Kusa H, Ruzek P, lusek J, Losak T. Boron availability and uptake under increasing phosphorus rates in a pot experiment. Plant Soil and Environment. 2017; 63: 483-490.

[18] Han S, Li-Song C, Huan-Xin J, Brandon RS, Lin-Tong Y, Cheng-Yu X. Boron efficiency decreases growth and photosynthesis, and increases starch and hexoses in leaves of citrus seedlings. Journal of Plant Physiology. 2008; 165(13): 1331-1341.

[19] Kumar P, Pandey S, Singh B, Singh S, Kumar D. Influence of source and time of potassium application on potato growth, yield, economics and crisp quality. Potato Research. 2007; 50(1): 1-13.

[20] Mengel K, Kirkby E. Principles of plant nutrition, 4th ed. International Potash Institute. Bern. 1987.

[21] Puzina, TI. Effect of zinc sulphate and boric acid on the hormonal status of potato plants in relation to tuberization. Russian Journal of Plant Physiology. 2004; 51(2): 209-215.

[22] Rashid A, Yasin M, Ashraf M, Mann RA. Boron deficiency in calcareous soil reduces rice yield and impairs grain quality. International Rice Research Notes. 2004; 29(1): 58-60.

[23] Jahan SA, Alim MA, Hasan MM, Kabiraj UK, and Hossain MB. Effect of potassium levels on the growth, yield and yield attributes of lentil. International Journal of Sustainable Crop Production. 2009; 4(6): 1-6.

[24] Samiullah, Khan NA. Physiological investigation on interactive effect of P and K on growth and yield of chickpea. Indian Journal of Plant Physiology. 2003; 8(2): 165-170.

[25] Haque N. The growth and yield of mungbean as influenced by potassium and sulphur [MS Thesis]. Department of Agronomy. Sher-e-Bangla Agricultural University, Dhaka, Bangladesh; 2013.

[26] Budhathoki C, Subedi M, Subedi K. Variation in sterility among wheat (Triticum aestivum L.) genotypes in response to boron deficiency in Nepal. Euphytica.1997;95:21-26.

[27] Kaisher MS, Rahman AM, Amin MHA, Amanullah ASM, Ahsanullah ASM. Effects of sulphur and boron on the seed yield and protein content of mungbean. Bangladesh Research Publication Journal. 2010; 3(3): 1181-1186.

[28] Alam MR, Ali MA, Rafiquzzaman S, Ahmed B, Bazzaz M. Effect of phosphorus and boron on the performance of summer mungbean in high Ganges river floodplain soil. Journal of Agroforestry and Environment. 2010; 3(2): 183-186.

[29] Maqbool R, Ali W, Nadeem MA, Abbas T. Boron application in clay-Loam soil for improved growth, yield and protein contents of mungbean in water-stresses. Sains Malaysiana. 2018; 47(1): 51-58.

[30] Magda AE, Lamyaa A, El-Rahman ABD, Sayed DA. Effect of foliar application of boron and potassium sources on yield and quality of potato (Solanum tuberosum L.). Middle East Journal of Applied Sciences. 2020; 10(1): 120137.

[31] El-Dissoky RA, Kadar A.E.S. Effect of boron as a foliar application on some potatoes cultivars under Egyptian alluvial soil conditions. Research Journal of Agricultural and Biological Sciences. 2013; 232-240. 